\title{
Adrenomedullin in Mammalian Embryogenesis
}

\author{
MERCEDES GARAYOA, ${ }^{1 *}$ ELENA BODEGAS, ${ }^{1}$ FRANK CUTTITTA, ${ }^{2}$ AND LUIS M. MONTUENGA ${ }^{1}$ \\ ${ }^{1}$ Department of Histology and Pathology, Carcinogenesis Unit, University of Navarra, 31080 Pamplona, Spain \\ ${ }^{2}$ Department of Cell and Cancer Biology, Medicine Branch, Division of Clinical Sciences, National Cancer Institute, \\ Bethesda, Maryland 20892
}

\begin{abstract}
Here are summarized data supporting that adrenomedullin (AM) is a multifunctional factor involved in the complex regulatory mechanisms of mammalian development. During rodent embryogenesis, AM is first expressed in the heart, followed by a broader but also defined spatio-temporal pattern of expression in vascular, neural, and skeletal-forming tissues as well as in the main embryonic internal organs. AM pattern of expression is suggestive of its involvement in the control of embryonic invasion, proliferation, and differentiation processes, probably through autocrine or paracrine modes of action. AM levels in fetoplacental tissues, uterus, maternal and umbilical plasma are highly increased during normal gestation. These findings in addition to other physiological and gene targeting studies support the importance of AM as a vasorelaxant factor implicated in the regulation of maternal vascular adaptation to pregnancy, as well as of fetal and fetoplacental circulations. AM is also present in amniotic fluid and milk, which is suggestive of additional functions in the maturation and immunological protection of the fetus. Altered expression of AM has been found in some gestational pathologies, although it is not yet clear whether this corresponds to causative or compensatory mechanisms. Future studies in regard to the distribution and expression levels of the molecules known to function as AM receptors, together with data on the action of complement factor $\mathrm{H}$ (an AM binding protein), may help to better define the roles of AM during embryonic development. Microsc. Res. Tech. 57:40-54, $2002 . \quad \odot 2002$ Wiley-Liss, Inc.
\end{abstract}

\section{INTRODUCTION: MOLECULAR SIGNALS IN DEVELOPMENT}

Morphogenesis of multicellular organisms is highly dependent on cellular interactions mediated through secreted or membrane-displayed factors. These signals influence neighbouring cells to modulate their developmental fate through the regulation of the expression of the relevant genes. In the last decades, Developmental Biology has accumulated information on a variety of secreted factors that are involved in the control of the highly synchronized processes that occur during embryogenesis. The local autocrine-paracrine effect of a given factor on the neighboring cells is not the only way of action for these molecular signals. The relevance of the changes in the concentration levels while the factor diffuses away from its source has also been repeatedly demonstrated. This gradual distance-depending effect of a signalling molecule over its target cell, together with the variety of factors influencing each cell at a given time point, and the positive and negative feedback loops that each signal provokes, makes the control of gene expression during embryogenesis a very complex field, as any cellular response is the effect of a multifactorial cause. Even if the response of isolated cells to a single factor may be known for a given cell type, the integration of cellular responses to a set of multiple signals and the effects due to cell-cell interaction in the context of a forming organ are still not well understood (Fraser and Harland, 2000). In any case, the pursuit of new players of developmental control continues. In mammalian embryogenesis, an increasing number of secreted peptides have been shown to be implicated in the long-term modulation of growth, differentiation, cell migration, and cell death (Nilsen-
Hamilton, 1990). The present review summarizes the data supporting that Adrenomedullin (AM) and its related peptide the proAM N-20 peptide (PAMP), are growth factors potentially involved in the complex regulatory mechanisms of mammalian development.

\section{ADRENOMEDULLIN IN MAMMALIAN DEVELOPMENT}

The expression of AM has been described in a variety of adult animal and human tissues, including heart, adrenals, brain, kidney, pancreas, aorta, lung, and brain- and lung-derived tumors (Cameron and Fleming, 1998; Cuttitta et al., 1999; Miller et al., 1996; Montuenga et al., 1997; Washimine et al., 1995). These observations, together with the data linking AM to growth control in normal and tumor cells prompted us to investigate the possible role of AM on embryogenesis (Montuenga et al., 1997, 1998). Although the localization of AM in adult mammalian tissues and human neoplasms has already been the object of some studies, and the role of AM in normal and pathological physiology is now being clarified, the functional relevance of AM during embryogenesis is still obscure. Our studies showing a broad expression of AM in many forming organs of mouse and rat embryos support a strong involvement of AM during the embryonic and fetal periods. In those studies, we analyzed AM expression in mouse (E8-E16) and rat (E10-E18) development by

\footnotetext{
Contract grant sponsor: Ministerio de Educación y Cultura, Spain; Contract grant number: PB 98-0211.

*Correspondence to: Mercedes Garayoa, Department of Histology and Pathology, Carcinogenesis Unit, University of Navarra, 31080 Pamplona, Spain. E-mail: mgarayoa@unav.es

Received 7 June 2001; accepted in revised form 30 July 2001
} 
means of molecular, biochemical, and histochemical techniques.

In the following, we will summarize the current literature on the expression of AM in developing mammals. First, we will comment on studies related to the expression of AM in mouse and human placenta and other structures at the early developmental stages. Secondly, we will review data with regard to the expression of proAM-derived peptides during mouse and rat morphogenesis and organogenesis. Most of the data that we will present are derived from our original studies on mouse and rat embryos (Montuenga et al., 1997, 1998). Other authors have subsequently published a number of data confirming our results and this will also be discussed. Finally, studies on the levels of AM in normal pregnancy and changes of AM levels in some pregnancy-related pathologies will be reviewed.

\section{AM IN EARLY DEVELOPMENTAL STAGES}

\section{AM in Fetoplacental Tissues}

The studies from our group demonstrated the presence of intense AM-like immunoreactivity in the primitive placenta at early rodent embryogenesis (mouse $\mathrm{E} 8$, rat E11) when low immunoreactive signal for $\mathrm{AM}$ is found in the developing embryonic tissues (Montuenga et al., 1997). Specifically, AM is expressed in embryonic cells of the ectoplacental cone, with very prominent AM protein and mRNA staining in trophoblast giant cells (see Figs. 1-3). Immunocytochemical AM staining was also present in maternal decidual cells, endodermal cells lining the yolk sac, and to a lesser extent in the chorionic plate. Using an in situ hybridization technique, the specific L1 AM receptor (Kapas et al., 1995) mRNA was also localized to several cell types of the developing placenta, again with distinct expression in trophoblast giant cells (Fig. 4) (Montuenga et al., 1997). Subsequently, a more detailed study of AM expression at the peri-implantation stage was conducted (Yotsumoto et al., 1998), since AM was found to be one of the genes highly expressed in a cDNA library from the ectoplacental cone of 7 days postconception (d.p.c.) mouse embryos. Confirming our previous data, AM expression was mainly detected in trophoblast cells in the ectoplacental cone, being most highly expressed in trophoblast giant cells. Because of the timing of AM expression in these cells (AM mRNA starts to be detected at 6.5 d.p.c., peaks at 9.5 d.p.c., and falls to a much lower levels after 10.5 d.p.c.), it was proposed that AM may act on the blood vessels by pooling maternal blood in the implantation site, securing nutrition and $\mathrm{O}_{2}$ at this early postimplantation period when an efficient chorioallantoic placenta is not yet established (Yotsumoto et al., 1998). These authors, however, did not find a detectable expression of the L1 AM receptor in extraembryonic tissues by Northern blot analysis. Different sensitivity levels of Northern blot and in situ hybridization techniques could be claimed as the cause for the discrepancy with our results. However, the functional response of the $\mathrm{L} 1$ receptor (Kapas et al., 1995) or its human homologue (Hänze et al., 1997) as AM receptors has recently been questioned (Kennedy et al., 1998), and thus caution is needed with regard to this piece of data in placental tissues. The expression of other molecules known to function as AM receptors, such as RDC-1 (Kapas and Clark, 1995), CRLR/Receptor activity modifying protein (RAMP)2 and CRLR/RAMP3 (Chang et al., 1993; McLatchie et al., 1998; Njuki et al., 1993), has not been studied specifically in rodent placental tissues and, therefore, awaits future investigations.

Likewise, human placental tissues have also been found to express AM protein and mRNA. Within human placenta at term, AM is localized primarily in extravillous trophoblast cells and in the syncytiotrophoblast, but is also present in endothelial cells of villous blood vessels and in maternal decidual cells (Di Iorio et al., 1998c; Kanenishi et al., 2000, 2001; Macri et al., 1998; Marinoni et al., 1998). Occasionally, immunocytochemical staining for AM has also been reported in cytotrophoblast cells and in the mesenchyma and inflammatory cells within the villi (Kanenishi et al., 2001; Macri et al., 1998). The fetal membranes, and, more specifically, the epithelium of the amniotic membrane, also show high levels of AM and its mRNA (Kanenishi et al., 2000, 2001; Kobayashi et al., 2000; Macri et al., 1996b; Makino et al., 1999c). The pattern and intensity of AM immunoreactivity in the first trimester human placenta and fetal membranes were reported to be similar to that in term pregnancy (Macri et al., 1996a; Kanenishi et al., 2001), suggesting that AM secreted from these sites might play an important role in the maintenance of normal pregnancy throughout gestation. Similarly to the above-mentioned situation in rodents, there is still limited information about the expression of the different AM receptors in human placenta. The mRNA for the human homologue to the rat L1 AM receptor has been localized to first trimester trophoblasts by in situ hybridization (Macri et al., 1998), and also discrete expression was found in placental tissues by Northern blot analysis (Hänze et al., 1997). Both human RAMP2 and RAMP3 mRNA have also been shown to be abundantly represented in human placenta as assessed by Northern blot analysis (McLatchie et al., 1998). Further investigation for cellspecific localization of the different AM receptor types in human placenta, together with parallel correlation with AM-binding and functional studies, are still needed to better define the possible functions of AM in this organ.

Successful mammalian embryonic development is obviously dependent first on the synchronized development of the fetoplacental vasculature, and subsequently on the maintenance of an adequate placental vascular tone to achieve sufficient gas and metabolite interchange between maternal and fetal circulations. In fact, the above-mentioned expression of AM in the villous mesenchyma together with the AM reported angiogenic properties (Nikitenko et al., 2000; Zhao et al., 1998), are suggestive of a possible role of this peptide in placental vasculogenesis at the early postimplantation stages. Because the placenta lacks autonomic innervation, the maintenance of an adequate uteroplacental perfusion is regulated mainly by systemic blood pressure changes through the action of both circulating and locally released vasoactive agents (Jaffe, 1998; Macara et al., 1993), keeping the placental vasculature in a state of near-maximal dilatation. It is noteworthy that the content of immunoreactive AM in placentas $(117.7 \pm 7.8 \mathrm{pg} / \mathrm{mg}$ wet tissue $)$ and fetal 

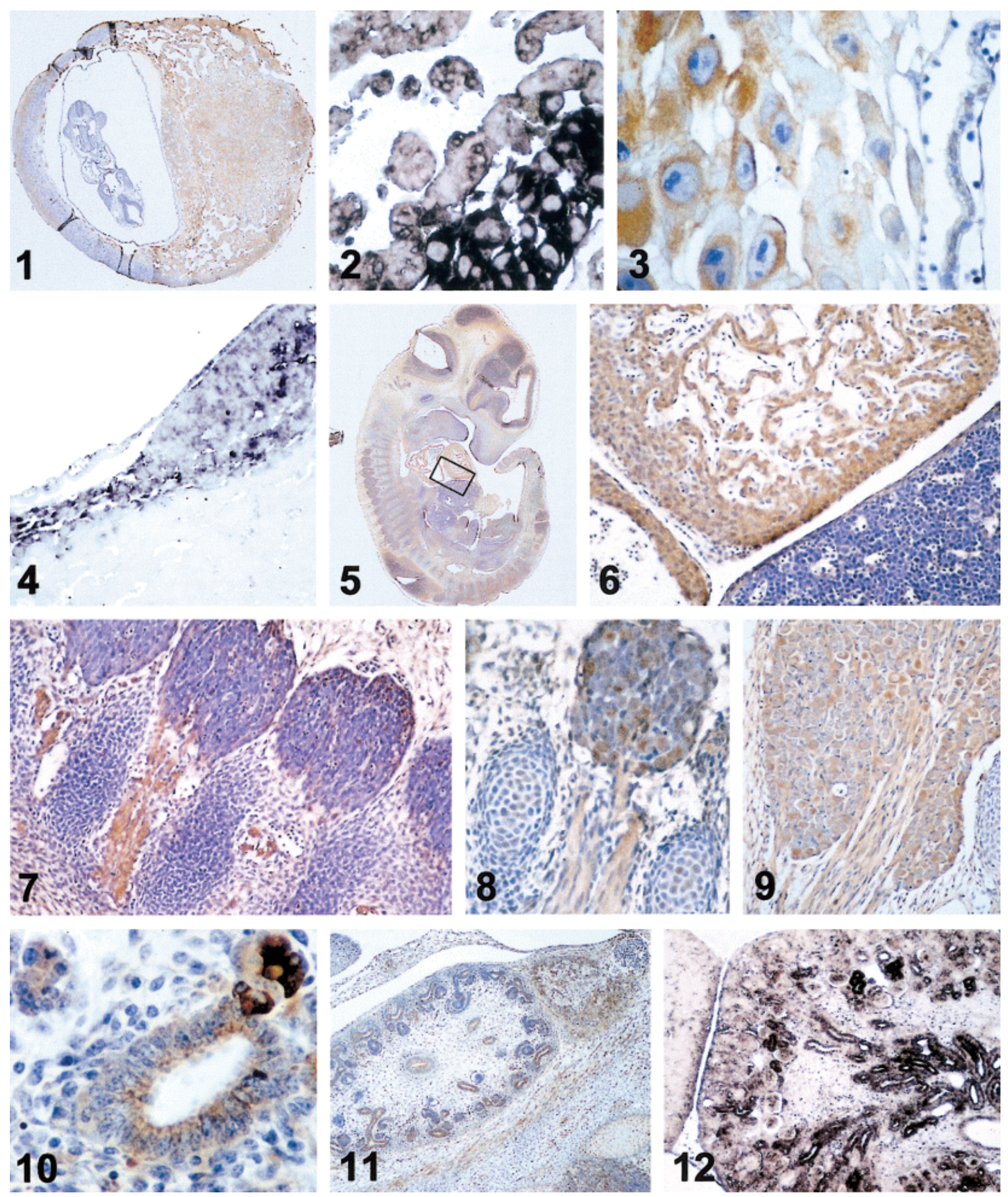

Fig. 1. Mouse E9. Primitive placenta and embryo immunostained for AM. $\times 13$.

Fig. 2. Mouse E9. Nonradiaoactive in situ hybridization for AM mRNA in the mouse placenta showing strongly positive giant trophoblastic cells. $\times 100$.

Fig. 3. Mouse E9. Giant trophoblastic cells of the mouse placenta immunostained for AM. $\times 250$.

Fig. 4. Mouse E8. In situ hybridization staining for the L1 AM receptor in the mouse primitive placenta. $\times 50$.

Fig. 5. Mouse E11. Section of the whole embryo immunostained for AM. Box: see Figure 6 legend. $\times 5$.

Fig. 6. Mouse E11. Detail of developing heart in a region similar to box in Figure 5. Atrium and ventricle are positive, whereas the liver primordium is not stained. Cardiomyocytes but not endocardial cells are positive for AM. $\times 120$.
Figs. 7-9. Mouse E11-E16. Expression of AM during maturation of dorsal root ganglia and cartilage. Condensing mesenchymal cells at the early stages of chondrogenesis are negative, as well as the young neurons of the early dorsal root ganglia (Fig. 7). Detectable levels of $\mathrm{AM}$ increase in later stages both in chondrocytes (Fig. 8) and neurons (Figs. 8,9). Fig. 7, E11 ×270; Fig. 8, E12 ×200; Fig. 9, E16 $\times 150$.

Fig. 10. Detail of the mouse E16 forming pancreas. Note positive primitive islets budding off the ducts in top right corner. $\times 400$.

Fig. 11. Rat E16 kidney. Metanephric duct and derived ducts are positively stained for AM. Top right: Immunostained tissue of the adrenal gland can also be observed. $\times 50$.

Fig. 12. Rat E18. In situ hybridization for AM mRNA in the kidney. Apart from the ducts, some cells of the differentiating glomeruli express AM mRNA. $\times 50$. 
membranes $(168.7 \pm 2.3 \mathrm{pg} / \mathrm{mg}$ wet tissue $)$ is comparable to the AM concentration in adrenal medulla (157.3 $\pm 74.4 \mathrm{pg} / \mathrm{mg}$ wet tissue) (Marinoni et al., 1998), thus being much higher than that found in other human tissues examined (Kim, 1999; Kitamura et al., 1998). Since AM has potent vasodilator properties (Kitamura and Eto, 1997; Letizia et al., 1999), the expression of AM in placenta and fetal membranes, together with high AM levels in pregnant uterus (Upton et al., 1997), maternal plasma, and amniotic fluid (Di Iorio et al., 1997b, 1999; Kanenishi et al., 2001), makes it likely that during normal pregnancy AM may contribute to the regulation of the placental vascular tone. Very interestingly, using isolated perfused placental cotyledons, AM was shown to cause vasodilatation of fetoplacental vasculature previously constricted with a thromboxane sympathomimetic (Hoeldtke et al., 2000 ), thus providing physiological support to the possible vasodilatory effect of AM in the regulation of fetoplacental vascular tone. However, since supraphysiological concentrations of AM were needed to produce this effect in vitro, AM was proposed to exert its putative vasodilatory action in the placenta acting locally through specific receptors in endothelial and vascular smooth muscle cells rather than as a circulating hormone (Hoeldtke et al., 2000).

Finally, it is of interest that calcitonin-a peptide belonging to the same family as AM, although with lower homology degree than CGRP or amylin (Wimalawansa, 1997) - is markedly induced in the pregnant rat uterus during implantation (Ding et al., 1994). In fact, the loss of calcitonin gene expression upon antisense treatment is accompanied by a severe impairment in the implantation of embryos (Zhu et al., 1998). Thus, it looks as if the presence and function of at least some members of the calcitonin family of peptides (calcitonin and $\mathrm{AM}$ ) in the endometrium and/or placental tissues may play important roles in implantation and in the maintenance of normal placental function.

\section{Expression of AM in In Vitro Models of Early Embryo}

Human placental development depends critically on the differentiation of the placenta's specialized epithelial cells, termed trophoblasts (Cross et al., 1994; Fisher and Damsky, 1993). Two natural differentiation fates exist for this cell type: in one, trophoblasts remain in flotating villi and fuse to form the highly specialized syncytiotrophoblast layer that covers the flotating chorionic villi; being in direct contact with maternal blood, the syncytiotrophoblast contributes to gas, nutrient, and waste exchange for the fetus. Alternatively, a subset of trophoblast cells in anchoring villi proliferate and generate a multilayered column of extravillous trophoblasts. These extravillous trophoblasts later migrate to the uterine wall and invade as far as the first third of the myometrium, inducing remodelling of the spiral arterioles to produce the low-resistance vascular system that is essential for fetal growth (Genbacev et al., 2000).

One of the feature characteristics of first trimester human trophoblast cells is that, similarly to malignant tumor cells, they are inherently invasive (Fisher et al., 1989; Librach et al., 1991; Yagel et al., 1988). In fact, these invasive trophoblasts exhibit some of the molec- ular mechanisms of invasion typical of tumoral cells, such as production of significant levels of type IV collagenase and laminin required for basement membrane invasion (Librach et al., 1991; Yagel et al., 1988), and expression of matrix metalloproteinases and plasminogen activators (Harvey et al., 1995). However, unlike tumoral cells, invasive trophoblasts in vivo do not have the ability for unlimited growth or metastasis, but rather their invasiveness is under strict control both in a spatial and temporal manner. This control seems to be dependent on a repertoire of growth factors largely produced by decidual cells of the uterus, and to a minor extent also derived from the trophoblasts themselves. For instance, transforming growth factor $\beta$ (TGF $\beta$ ) seems to be a key mediator against trophoblast invasion in vivo by inducing tissue inhibitor metalloproteinases (TIMPs) production in the decidua as well as in trophoblasts (Graham and Lala, 1991). Interestingly, AM expression in maternal decidual cells as well as in trophoblast giant cells in mouse placenta has been found to colocalize with that of TGF $\beta 1$ (Montuenga et al., 1998); this concomitant expression may be of relevance if these two factors have opposite modulatory properties to exert on the invasiveness of trophoblast cells. In the same sense, other factors such as leukemia inhibitory factor (LIF) and epidermal growth factor (EGF), which are produced by the uterine endometrial glands and luminal epithelium, respectively, have also been found to differentially regulate matrix metalloproteinases and plasminogen expression in peri-implantation blastocysts, thus modulating invasiveness at the implantation stages (Bass et al., 1994; Harvey et al., 1995).

The differentiation of human placental trophoblast cells into a syncitium has been simulated in an in vitro culture system by the action of EGF (Morrish et al., 1987, 1996). Other factors such as colony stimulating factor-1 (CSF-1) and granulocyte-macrophage colony stimulating factor (GM-CSF) also stimulate (GarcíaLloret et al., 1994; Morrish et al., 1987), whilst TGF $\beta 1$ inhibits (Morrish et al., 1991) in vitro biochemical and morphological syncytiotrophoblast differentiation. Interestingly, using a subtractive hybridization procedure, AM was found to be one of the genes whose expression was increased by EGF-induced differentiation (Morrish et al., 1996). It is not known, however, whether AM might represent a genetic indicator of EGF action in the differentiating trophoblast or a byproduct of the differentiated phenotype.

In addition to its role in nutrient, gas, and waste exchange, the syncytiotrophoblast is also considered to be an endocrine tissue implicated in the synthesis and secretion of steroid and peptide hormones (Cross et al., 1994; Morrish et al., 1987; Yagel et al., 1989). In adults, $\mathrm{AM}$ has been found to influence the secretion rate of several hormones such as insulin, adrenocorticotropin, catecholamine, aldosterone, and renin (Hirata et al., 1995; Katoh et al., 1995; Martínez et al., 1996; Samson et al., 1995; Yamaguchi et al., 1995). The AM expressed in the syncytiotrophoblast may also have a similar role as a hormone secretion regulator.

There are no studies available regarding the presence and function of AM in early embryonic cells. AM and PAMP have been reported to be biologically active in some embryonic carcinoma cell lines, which have 
TABLE 1. Tissue distribution of immunohistochemically detectable AM in mouse organogenesis ${ }^{1}$

\begin{tabular}{|c|c|c|c|c|c|c|c|c|c|c|c|}
\hline Tissue & Localization & E8 & E9 & E10 & E11 & E12 & E13 & E14 & E15 & E16 & \\
\hline Heart & & 1 & 2 & 3 & 3 & 3 & 3 & 3 & 3 & 3 & \\
\hline Arterial vasculature & & & & 1 & 2 & 2 & 2 & 2 & 2 & 2 & \\
\hline \multirow{3}{*}{ Central nervous system } & Brain & 0 & 0 & 1 & 1 & 1 & 1 & 1 & 1 & 2 & \\
\hline & Pituitarv & & & & 1 & ND & ND & 1 & 1 & 1 & \\
\hline & Choroid plexus & & & $0 / 1$ & 2 & 2 & 2 & 2 & 2 & 2 & \\
\hline \multirow[t]{2}{*}{ Peripheral nervous system } & Spinal cord & 0 & 0 & 1 & 1 & 1 & 2 & 2 & 2 & 2 & \\
\hline & Dorsal root ganglia & & & 0 & $0 / 1$ & 1 & 2 & $2 / 3$ & 3 & 3 & \\
\hline Eye & Retina & & & & & 0 & 0 & 0 & $0 / 1^{2}$ & $0 / 1^{2}$ & \\
\hline Ear & Choclear epithelium & & & & 0 & 1 & 1 & 1 & $1 / 2$ & 2 & \\
\hline \multirow{6}{*}{ Skeletal structures } & Skeletal muscle & & & & 0 & 1 & 2 & 2 & 2 & 2 & \\
\hline & Precartilaginous blastema & & & & 0 & & & & & & \\
\hline & Perichondrium & & & & 0 & 0 & 0 & $0 / 1$ & 0 & 0 & \\
\hline & Chondrocytes & & & & 0 & 1 & 2 & 2 & 2 & 2 & \\
\hline & Hypertrophic cartilage & & & & & & & 3 & 2 & 2 & \\
\hline & Osteoblasts & & & & & & & 2 & 2 & 3 & \\
\hline \multirow[t]{2}{*}{ Skin } & & & & & 1 & 2 & 2 & 2 & 2 & 2 & \\
\hline & Whisker follicles & & & & & & & 1 & 2 & 2 & 2 \\
\hline \multirow[t]{2}{*}{ Intestine } & Epithelium & & & & & 1 & 1 & 1 & 1 & 2 & \\
\hline & Muscle fibers & & & & & 1 & 2 & 2 & 2 & 2 & \\
\hline \multirow[t]{2}{*}{ Liver } & Hepatocytes & & & & 0 & 0 & 0 & 1 & 1 & 1 & \\
\hline & Megakaryocytes & & & & 1 & 1 & 1 & 1 & 1 & 1 & \\
\hline \multirow[t]{2}{*}{ Thymus } & Cortex & & & & & & ND & 0 & 0 & 0 & \\
\hline & Medulla & & & & & & ND & 0 & 1 & 1 & \\
\hline \multirow[t]{3}{*}{ Lung } & Epithelial cells & & & 0 & 1 & 1 & 1 & $1^{3} / 0^{4}$ & $1^{3} / 1^{4}$ & $0^{3} / 2^{4}$ & \\
\hline & Mesenchyma & & & $0 / 1$ & 0 & 1 & 1 & 1 & 1 & 1 & \\
\hline & Airway smooth muscle cells & & & & & & & $0 / 1$ & 1 & 1 & \\
\hline \multirow[t]{3}{*}{ Kidney } & Metanephric duct derivatives & & & & & 0 & 2 & 2 & 2 & 2 & \\
\hline & Forming tubules & & & & & 0 & 0 & 0 & 0 & 1 & \\
\hline & Glomeruli & & & & & 0 & 0 & $0 / 1^{5}$ & $1^{5}$ & $1^{5}$ & \\
\hline Adrenal gland & & & & & & 1 & 2 & 2 & 2 & 2 & \\
\hline
\end{tabular}

${ }^{1}$ Staining intensity is ranked from 0 (no staining) to 3 (very intense staining). ND, not determined.

${ }^{2}$ Outer neuroblastic layer.

${ }^{3}$ Prospective respiratory system.

${ }^{4}$ Prospective bronchial system.

${ }^{5}$ Glomerular capillary and mesangial tufts.

similar properties to pluripotent cells of the inner mass of the blastocyst (Moody et al., 2000). In binding studies using the teratocarcinoma PA-1 cell line, AM seemed to act through $\mathrm{CGRP}_{1}$ type receptors, stimulated adenylyl cyclase, c-fos mRNA expression, and cell proliferation. PAMP, on the contrary, bound to a different class of receptors, and inhibited or reversed the actions caused by AM (Moody et al., 2000). Likewise, the authors suggested that PAMP might also be a physiological antagonist of AM in vivo having a somehow compensatory role for AM during embryonic development, although this hypothesis remains to be proven.

\section{AM IN MORPHOGENESIS AND ORGANOGENESIS}

Table 1 summarizes our data on mouse immunoreactivity for AM embryos (E8-E16). In situ hybridization for AM mRNA shows a parallel anatomical distribution. Although not shown here, RT-PCR and Northern blot analyses of isolated total mRNA both in rat and mouse embryonic tissues confirmed the presence of $\mathrm{AM}$ and the AM receptor (L1) message (Montuenga et al., 1997, 1998). As a general outline, we have shown that the pattern of appearance and distribution of AM immunoreactivity in the rat is very similar to that of the mouse, but happens 1.5-2 days later in development. Nevertheless, some differences are found between the two species. In general, the later stages of development of rat embryos showed higher levels of AM-immunoreactivity than the equivalent stages in the mouse. Here is presented mainly the data corresponding to the mouse embryo and, when a significant variation exists, the peculiarities found in rat development.

\section{Cardiovascular System}

The first organ to express AM in the developing mouse embryo is the forming heart. On day 8, the walls of the common atrial and ventricular chambers of the primitive heart show slight immunoreactivity for AM. In the E9 embryo, the cardiac tube is markedly immunostained with the same antibodies. Throughout all the following stages of the mouse development, the developing heart is the organ that shows higher levels of immunoreactivity (Figs. 5,6). The myocytes of both atrial and ventricular walls, including the elaborate trabeculae formed around E10 in the ventricular chamber, strongly express AM. The differentiating smooth muscle fibers that are found in the large arteries at E11 are also very immunoreactive for AM. Cormier-Regard et al. (1998), using the technique of differential display, reported that the AM gene was differentially expressed in developing rat heart. The RT-PCR analysis performed by these authors revealed that the level of AM mRNA was significantly higher in adult ventricular cardiac muscle as compared with embryonic day 17 ventricular cardiac muscle. As we also reported for the mouse embryos, Cormier-Regard et al., showed that the AM receptor mRNA (L1) was constitutively expressed throughout development of the rat ventricular heart. In our studies in the embryonic rat, endothe- 
lial cells expressed AM earlier than in the mouse equivalent stage and in a broader pattern. AM-immunoreactive endothelial cells could be found as early as the E10 stage in the rat embryo and were also found in some very small vessels such as the ones in developing glomeruli at E16-17. In the developing mouse embryo, the smaller blood vessels were less frequently stained for AM.

\section{Nervous System}

At mouse E10, the neural tube starts producing AMlike material. In this stage, the maturing cells of the ventral horn of the spinal cord stain for AM. On E12 and the following days, the contrast between differentiated stained and less differentiated unstained areas of the central nervous system is clearer. From E12 on, specific groups of neurons positive for AM can be observed in the central nervous system, for example in the mantle layer of the spinal cord. Neural crest-derived dorsal root ganglia and their segmental nerve trunks become increasingly immunostained from E11E12 onwards (Figs. 7-9). Throughout the rest of the development, AM will be localized to the neuropil, individual or grouped neurons within the central nervous system and the dorsal root ganglia (Figs. 8,9). A certain segmental progression in the degree of staining of dorsal root ganglia is also detected within a given stage, suggesting that AM expression goes in parallel with sensory neuron maturation. A detailed map of the expression of AM in the adult rat has been already published (Serrano et al., 2000) showing a widespread presence of this peptide throughout the rat central nervous system. Recently, the relevance of AM in eye physiology has been shown (Taniguchi, 1999). Our data on the developing eye also showed a discrete immunocytochemical signal in the outer neuroblastic layer of the retina at E14-E15. In situ hybridization showed that the mRNA for AM is also present in the same cells.

\section{Skeletal and Integumentary Tissues}

AM-immunoreactive material and mRNA could be detected in groups of mouse mesenchymal cells from day 9. The expression of AM by the mesenchymal cells seems to follow precise patterns of spatio-temporal distribution, as the degree of staining of this tissue varied from one region to the other and during development. The expression of AM in undifferentiated early mesenchymal cells may be relevant and deserves further attention, especially after the numerous reports showing the broad differentiation potential of mesenchymal stem cells (Pittenger et al., 1999). In the E12-E13 stage, when the differentiation of the cartilaginous skeleton proceeds from condensed mesenchyma/precartilage towards more mature chondrocytic cells, AM-like material starts to be expressed. Condensing mesenchy$\mathrm{mal} /$ precartilage cells are immunocytochemically negative for AM whereas maturing cartilage and hypertrophic cartilage cells are increasingly positive from mouse E13. Osteoblasts of the developing bone are consistently immunoreactive for AM. Interestingly, Cornish et al. (1997) have shown that the addition of AM increases $\left[{ }^{3} \mathrm{H}\right]$-thymidine incorporation into cultured neonatal mouse calvaria in a dose-dependent way. Cornish et al. (1997) also show that AM increases cell number and $\left[{ }^{3} \mathrm{H}\right]$-thymidine incorporation in cul- tures of fetal rat osteoblasts. The role of AM in bone morphogenesis and repair deserves further detailed studies, which could be very relevant to bone pathology and therapeutics.

The striated muscle cells were also immunoreactive for AM once they differentiated. This is particularly evident between mouse E12 and E14, when the tongue elongates and increases in volume and the striated muscle fibers differentiate from the corresponding myotubes. AM-like expression is observed in the outer layer of the early skin, the periderm, from the E10 stage and increases its expression in the epidermal cells of the more differentiated skin on day 14 and throughout the whole developmental stages that follow. AM mRNA and the mRNA for the L1 AM receptor could also be found by in situ hybridization in the forming skin. Martínez et al. (1997) have shown that $\mathrm{AM}$ is an autocrine growth factor in human normal and malignant keratinocytes, suggesting that the role of $\mathrm{AM}$ present in the forming skin may also be related to the control of proliferation of the nascent keratinocytes during fetal skin formation. Both in the fetal mouse and rat, the cells that form the outer layer of the forming hair follicles are also immunostained for AM.

\section{Embryonic Internal Organs}

Apart from the heart, other internal organs express $\mathrm{AM}$ in the mouse embryo. In the gut, development progresses in a proximal to distal direction so that at one time point different segments of the gut are at various stages of maturation. Initially, when the lumen of the gut is small and is lined by a pseudostratified columnar epithelium, no AM staining is observed. In $\mathrm{E} 13$, as the gut matures, $\mathrm{AM}$ expression is found in the mesenchymal cells that will form the gut muscle layer. From E14 onwards, the presence of AM in the epithelium increases. In E16, the more differentiated simple columnar intestinal epithelium shows expression of AM located mainly in the apical region of the enterocytes. While the pancreatic primordia are initially negative for AM, at E14 a number of cells at the developing pancreatic ducts become immunoreactive for AM (Fig. 10). These are the primordia of the endocrine islets, budding off the ducts. The pattern of colocalization of AM with the other pancreatic hormones has also been followed during rat pancreatic development (Martínez et al., 1998); it was found that at some point during development, all the endocrine cell types express AM, progressively evolving towards the adult pattern where only the pancreatic polypeptide-cells contain a strong immunoreactivity for AM. A clear AM staining for differentiated hepatocytes was found in the liver of the E17 rat embryo, which was less apparent in the equivalent stage of mouse development. In the adult rat liver, no AM immunostaining is usually found. In the early developing mouse lung, there is no expression in the airway epithelium and very little in the mesenchyma that surrounds it. On day 11-12, the epithelium of the primordia of the bronchial tree shows incipient staining that tends to concentrate in the apical regions. In E13-E14 mouse embryos, lung mesenchymal expression of AM is present. In particular, the cells surrounding the developing bronchi that will differentiate into smooth muscle cells stain particularly strong. Smooth muscle fibers of the forming arteries also seem 
to express high levels of AM-immunoreactive material at this stage. In E15-E16 embryos, staining for AM is also found in the epithelial cells of the forming airways. Interestingly, Northern blot analysis of mRNA extracted from mouse fetal lung and gut show very high levels of RAMP-2 (Husmann et al., 2000), which would allow the signalling through AM, supporting our view that autocrine and paracrine regulation via AM may take place during gut and lung organogenesis. During the formation of the kidney, the first AM expressing cells are found at mouse E13-14/rat E16 in the epithelium of the metanephric duct and later on in the metanephric collecting tubules, but not in the mesenchyma from which primitive glomeruli forms (Fig. 11). AM expression is found in the epithelium of the developing nephrons at the S-shape body stage and, in the final stages of development, in the endothelial cells of the capillary and mesangial cell tufts of the developing glomeruli (Fig. 12). AM-immunoreactive material can also be found in the primordia of the adrenal glands from mouse E13-14 or rat E16 (Fig. 11). The immunoreactivity is more prominent in the medulla than in the cortex of the adrenal, as can be expected from the data published for the adrenal gland in adult mammals. The mRNA for AM follows the same pattern of distribution at this stage.

\section{Possible Roles of AM in Mammalian Morphogenesis and Organogenesis}

The results of our study and those of others strongly indicate that AM-mediated signaling is present in a large number of embryonic and extraembryonic cells and tissues during mouse and rat development. In these species, the onset of the increasing expression of AM-like peptide and mRNA occurs at the early organogenesis period. Initially, it is restricted to limited regions of the embryo, but seems to be present in most of the tissues and organs in the final stages of development. The widespread localization of AM that we have just described and the known multifunctional properties of the proAM derived peptides suggest that during development $\mathrm{AM}$ may have multiple roles in a variety of tissues and organs. Data concerning the localization of the L1 AM receptor (Montuenga et al., 1997) and the expression of AM-related RAMPs in some fetal organs (Husmann et al., 2000; Sexton et al., 2001) give further support to the active role of AM during development and suggest autocrine or paracrine modes of action.

Our results on the localization of AM and the L1 AM receptor, together with the available data on AM diverse functions, have led us to formulate the hypothesis that AM could be involved in the regulation of mammalian morphogenesis possibly through the control of cell proliferation, differentiation, and migration. The mitogenic of AM properties of AM on normal and malignant cells is thoroughly discussed by Cuttitta et al. (see Part II of this special issue). One of the first cell types on which the proliferative effect of AM was shown was embryonic mouse fibroblasts (Withers et al., 1996). Many reports coincide by showing that the mitogenic effects are dependent on a cAMP signal. In a recent report, we have shown that $\mathrm{AM}$ binds to human PA-1 teratocarcinoma cell lines and elicits a cAMP response together with an increase in $\left[{ }^{3} \mathrm{H}\right]$-thymidine incorporation (Moody et al., 2000). AM has also been found to be expressed and to have specific effects on several lineages of embryonal, fetal, and neonatal origin, such as rat osteoblasts (Cornish et al., 1997), rodent cardiomyocytes (Cormier-Regard et al., 1998; Tsuruda et al., 1998), rat cardiac fibroblasts (Tsuruda et al., 1999), and other embryonic fibroblasts (Coppock et al., 1999; Isumi et al., 1998, 1999). Interestingly, in some cell types, like mesangial and vascular smooth muscle cells, AM seems to act also as an inhibitor of proliferation, also through a cAMP-mediated signal.

A functional relationship between the expression of $\mathrm{AM}$ and differentiation can be deduced by the anatomical distribution of AM immunoreactivity and mRNA. In many of the embryonic organs, AM expression seems to correlate with the onset and progression of the differentiation process. For example, in the formation of the cartilaginous templates that precede bone, AM and the AM L1 receptor seem to be expressed in the more mature cell types in the chondrocyte lineage, including the hypertrophic cells, while the condensing mesenchymal cells that are present in the previous stages express very low, if any, levels of the peptide and its receptor (Fig. 7). Another example in which the expression of AM seems to be associated with the degree of differentiation is the neural tissue. While in the early neural tube neither immunocytochemical signal for AM nor mRNA of the ligand or the L1 receptor is observed, later on AM is present in many of the differentiated regions of the central nervous system. The expression of AM in the neurons of the sensory ganglia is also increased in the later stages of development (compare Figs. 7 and 9), especially from the moment when most of the dorsal root ganglia neurons are probably formed. Moreover, the well-established craneocaudal developmental delay in neuronal maturation of the sensory ganglia clearly correlates with differences in the levels of AM expression (unpublished data).

Finally, a possible role of AM in regulating cell migration is supported by the expression of this ligand and the mRNA for the L1 AM receptor in migratoryinvasive cells of the embryo, such as the giant trophoblastic cells, the forming blood vessels, or the neural crest-derived cells. AM has already been proposed as a proangiogenic molecule (Nikitenko et al., 2000; Zhao et al., 1998). Reported cell motility-related effects of AM are the stimulation of liver stellate cell relaxation through a cytoskeletal reorganization (Kawada and Inoue, 1994), and the inhibition of angiotensin II-stimulated glomerular mesangial and vascular smooth muscle cell migration (Kohno et al., 1997, 1999).

The formation of organs during embryogenesis is highly dependent on the sequential and time-regulated expression of a number of growth factors (Nilsen-Hamilton, 1994). The pattern of distribution of AM-like immunoreactivity and its mRNA during murine development is very similar to that of other well-established peptide growth factors. As mentioned before, we have also performed a detailed study comparing the distribution of AM protein and mRNA with those of TGF $\beta 1$ in mouse and rat embryos (Montuenga et al., 1998). Our study shows that the expression of TGF $\beta 1$ and AM is regulated in a spatial and temporal manner, such that overlapping patterns of expression occur in several tissues at the same stage of development and in 
the same cellular location in rodent embryogenesis. These data suggest that AM and TGF $\beta 1$ could be involved in analogous functions in relation to the forming of new tissues and organs. AM distribution also shows some coincident locations with other active peptides like platelet-derived growth factor (PDGF), the fibroblast growth factors, insulin-like growth factor (IGF)-I and II, and the recently discovered cardiotrophin, a member of the leukemia inhibitory factor/ interleukin- 6 family. On a comparative basis with the data available on growth factors, AM seems to be the peptide that is expressed in a larger variety of cells and tissues throughout development, which suggests that this peptide is an important requirement for development to proceed in most organs.

AM is abundantly expressed in areas where strong mesenchymal-epithelial interactions take place during development, such as kidney, lung, tooth primordia, and hair follicles. Other growth factors, such as IGF I and II, TGF $\beta 1$ and 2, and PDGF are also expressed in the developing kidney in a very specific spatial and temporal pattern, as happens for AM (Hammerman, 1995). Nevertheless, apart from localization, no functional data have been provided to support the relevance of AM in these cell-to-cell cross-talk processes. Further studies testing the effects of AM on the numerous available in vitro models for experimental morphogenesis are required.

\section{Expression of PAMP During Embryonic Development}

The expression of PAMP in the early embryo is still a matter of discussion. All the data available to date on the expression of PAMP in adult mammals show that the concentration of this peptide in the plasma or in tissues is always lower than that of AM. Consistent with these data, our early studies (Montuenga et al., 1997) showed a fainter immunoreaction for PAMP in most embryonic tissues, suggesting a lower level of expression as compared to AM.

\section{AM Receptors and AM Binding Proteins During Embryogenesis}

Born et al. (pages 14-22, this issue) deal with the issue of AM receptors and signal transduction. In any case, the field of AM receptors is still open and a matter of discussion, as several unrelated molecules have been proposed (Hinson et al., 2000; Poyner, 1997) and receptor activity modifying proteins are also involved (Sexton et al., 2001). As is true for several other growth factors involved in morphogenesis, such as PDGF or the several TGFßs/Bone Morphogenetic Proteins (BMPs), AM ligand co-localizes with one of its putative receptors (L1 receptor; Kapas et al., 1995) in a variety of developing organs. Also, Northern blot analysis of some mouse embryonic tissues have been found to abundantly express RAMP2 (lung and gut), whereas RAMP3 was mainly found in embryonic brain (Husmann et al., 2000; Sexton et al., 2001), therefore offering the possibility of AM action in these organs with a coexpressed CRLR receptor. These findings concerning the expression of different AM receptors during embryonic development support the hypothesis that AM may act locally in a short-range autocrine or paracrine mode. Once the area of AM receptors and RAMPs is settled, it will be very interesting to explore the developmental pattern of expression of every bona fide AM receptor in order to compare its distribution with that of the ligand. In this way, we will be able to understand the possible autocrine and paracrine interactions controlled by this peptide.

The recent discovery that the complement cascade protein factor $\mathrm{H}$ is a specific binding protein for $\mathrm{AM}$ and has functional modulatory properties for the action of AM on target cells (Pío et al., 2001) may also be relevant during development. In fact, factor $\mathrm{H}$ has been detected in fetal serum and amniotic fluid during human pregnancy (Stabile et al., 1988), it has been found to be synthesized by the amniotic membrane (Katz et al., 1995) and human umbilical vein endothelial cells (Brooimans et al., 1989), and is also present in fetal kidneys (Timmerman et al., 1996). The binding proteins provide an additional level of control via AM by a high-affinity locally secreted factor. This protein may modulate receptor activation by AM ligand as has been shown in the case of the binding proteins for the BMP and activin members of the TGF $\beta$ family of ligands. Several TGF $\beta$ binding proteins are currently the object of increasing interest in the context of vertebrate development-follistain, noggin, and chordin-which are particularly active in relation to the Spemann organizer, an area of the Xenopus embryo with endogenous dorsal inducing activity (Smith, 1999). As a general developmental concept, localized action of ligand inhibitory binding proteins can mask a group of cells from the inductive activity of the ligand while allowing nearby cells to respond. In this way, the same locally secreted ligand may have opposite effects in the neighbouring cells not only depending on the repertoire of expressed receptors, but also on the presence of variable concentrations of a diffusible inhibitory (or even stimulatory) binding protein. The existence of this AM binding protein may contribute to the regulatory actions of AM throughout embryogenesis.

In summary, there are still very sparse and limited data about the role of AM and PAMP in embryogenesis. Most of the assumptions are based on the sites of expression and by analogy with other multifunctional growth factors for which functional studies have been already performed. In any case, the available knowledge supports that AM may play an important role in a variety of key processes in embryonic development, namely in the control of growth, differentiation, and invasion. Further functional evaluation, on the basis of what is known through the distributional study, will clarify the validity of this hypothesis.

\section{CLINICAL ASPECTS RELATED TO THE LEVELS OF AM IN NORMAL PREGNANCY AND PATHOLOGICAL SITUATIONS}

\section{Normal Pregnancy AM Levels in Maternal Plasma, Amniotic Fluid, Umbilical Cord Plasma, and Milk}

AM in Maternal Plasma. Different research groups have shown elevated levels of AM in plasma of pregnant women at term (from 3 - to 5 -fold increase), as compared to levels in non-pregnant women or levels in the early puerperium (Di Iorio et al., 1999; Kanenishi et al., 2001; Kobayashi et al., 2000). Other vasoactive 
substances, such as endothelin, prostaglandin E2, and prostacyclin, have also been reported to increase in maternal plasma in a similar fashion (Brennecke et al., 1985; Goodman et al., 1982; Mastrogiannis et al., 1991). However, when comparing AM concentrations in plasma throughout pregnancy, some investigators have found no significant changes between different periods (Di Iorio et al., 1999), whereas others have reported increasing concentrations with advancing gestation (Kanenishi et al., 2001), or significant increases only in the third trimester (Kobayashi et al., 2000).

By use of a specific radioimmunoassay for the mature form of AM (amidated AM), Kamenishi et al. (2001) also determined the ratio between mature and total AM concentrations in maternal plasma throughout gestation. This ratio was found to be highest in the second trimester. Since the biological activity of mature AM has been reported to be $95 \%$ more potent than the activity from the glycine-extended form (immature), this difference could be indicative of more profound hypotensive effects of AM during the midgestational period (Kanenishi et al., 2001).

AM circulating in maternal plasma may derive from maternal or fetoplacental tissues, although lack of correlation between maternal plasma and amniotic fluid $\mathrm{AM}$ concentrations does not support the placental origin. More likely, the placenta together with several AM-producing maternal tissues [endothelial cells (Sugo et al., 1994), corpus luteum (Abe et al., 2000), pregnant uterus (Upton et al., 1997)], contribute to the increased maternal plasma levels of AM during pregnancy.

AM in Amniotic Fluid. Interestingly, significantly higher AM concentration has been found in amniotic fluid as compared to maternal plasma at any gestational age (Di Iorio et al., 1999; Kanenishi et al., 2001). The amniotic membrane, placenta, and the embryo proper are candidate sources for these elevated levels in the amniotic fluid (Di Iorio et al., 1999; Kanenishi et al., 2001; Macri et al., 1996b). Both total AM concentration in amniotic fluid (Di Iorio et al., 1999; Kanenishi et al., 2001), and the mature/total AM concentration ratio (Kanenishi et al., 2001) were significantly increased in late gestation. Future studies should elucidate the putative importance of this AM increase in the amniotic fluid on fetal organ development and/or maturation at this gestational period. Besides, AM has also been shown to have antimicrobial activity (Allaker et al., 1999; Walsh et al., 1998), and thus a protective role of $\mathrm{AM}$ in the amniotic fluid preventing fungal or bacterial infections during pregnancy has also been proposed (Macri et al., 1996b).

AM in Umbilical Cord Plasma. High AM levels have also been detected in umbilical cord plasma (Di Iorio et al., 1997b, 1999; Hoeldtke et al., 1998), although there are some discrepancies in the reported data concerning arterial and venous AM concentrations. Hoeldtke et al. (1998) found no significant differences between the umbilical arterial and venous plasma levels of AM, which would be indicative of neither net production nor net destruction of this peptide within the placenta. In contrast, AM concentrations were reported to be significantly higher in umbilical vein than in artery (Di Iorio et al., 1999), which in turn would favor the placental origin of AM in fetal circulation. Consistent with the latter proposal, no significant correlation was found between fetal and maternal AM plasma concentrations, thus supporting the view that AM in umbilical plasma is not derived from maternal circulation, but rather from the placenta (Di Iorio et al., 1999).

Under normal conditions of pregnancy, important physiological adaptations occur in the mother that ensure an adequate blood supply to the fetus. Peripheral resistance, mean arterial pressure, and sensitivity to vasopressor agents are reduced, whereas cardiac output, heart rate, and blood volume are increased (Carbillon et al., 2000; Macara et al., 1993). AM has been characterized as a key player in the modulation of blood pressure and vascular homeostasis in adult life through its well-documented vaxorelaxant effects (Kitamura and Eto, 1997; Letizia et al., 1999; Nuki et al., 1993). In this sense, it has also been found that patients with hypertension and renal failure show higher AM concentrations in plasma compared to normotensive control subjects (Ishimitsu et al., 1994). Since cultured endothelial and vascular smooth muscle cells posses specific receptors for this peptide (Ishizaka et al., 1994; Kato et al., 1995), it is fair to speculate that the increased AM levels in plasma of pregnant women might also be involved in reducing the maternal vascular resistance and mean arterial pressure during normal pregnancy, as well as regulating fetal and fetoplacental circulations. Physiological data in support of this view have come from a recent study using a model of hypertensive pregnant rats (Makino et al., 1999b). In this study, the elevated blood pressure and increased fetal mortality could be reversed by low-dose administration of $\mathrm{AM}$ in late gestation, therefore suggesting that AM plays an important role in the regulation of blood pressure, the blood supply to the uteroplacental unit, and fetal development in late gestation (Makino et al., 1999b). Other studies have also shown, however, that despite the elevated AM levels during pregnancy, the augmented depressor responsiveness to $\mathrm{AM}$ in late pregnant rats seems to be at least partially mediated by an increase in AM receptor density (Makino et al., 1999a). Additionally, it has also been shown that active metabolites of progesterone contribute to the stimulation of AM release during pregnancy (Jerat and Kaufman, 1998), which again is consistent with the role of AM as an endogenous modulator of vascular adaptation to pregnancy in association with the involvement of other hormones.

AM in Milk. Milk is known to contain several peptide hormones and growth factors including insulin, transferrin, lactoferrin, EGF, TGF, nerve growth factor, and IGF-I and II (Grosvenor et al., 1993; Koldovsky, 1992). These bioactive compounds are thought to play critical roles in the growth and development of the neonate, participating in physiological processes such as modulation of gastrointestinal functions, microbial growth control, and immunoregulation. AM was found to be expressed in the epithelium of mouse mammary gland, and also the fully processed AM peptide (Mr 6,000) was identified in milk extracts from lactating mice glands (Jähnke et al., 1997). Immunoreactive AM is also present in bovine and human milk, and human AM concentrations range between 140 to $404 \mathrm{pg} / \mathrm{ml}$, without an apparent pattern of 
change during the progression of lactation (Pío et al., 2000). Interestingly, AM in human milk exerted growth-promoting activity on a human intestinal cell line, which could be consistent with a putative role of this peptide in the regulation of secretor and motor functions in the gastrointestinal tract, as well as in the development and maturation of the intestinal epithelium in the period following birth (Pío et al., 2000). Other possible functions of AM in milk, such as pathogen protection (antimicrobial activity), modulation of tissue growth and development, or regulation of the immune system of the newborn, are still to be investigated.

\section{AM and Perinatal Adaptation}

In the fetus, since gas exchange occurs in the placenta, fetal pulmonary vascular resistance is high and pulmonary blood flow low, merely supplying nutritional requirements for lung growth and some metabolic functions. However, at the time of birth, with ventilation assumed by the lungs, dramatic changes in pulmonary circulation occur: pulmonary vascular resistance falls rapidly and pulmonary arterial blood flow increases approximately 8- to 10-fold (Heymann, 1999; Heymann and Soifer, 1989; Teitel et al., 1990). The control of the pulmonary vascular tone both in the fetus and during the transitional period to air-breathing is dependent on a complex and interactive group of mechanisms, including mechanical influences (e.g., endothelial shear stress, physical expansion, alveolar $\mathrm{pO}_{2}$ ) and a variety of endogenous vasoactive substances produced by the pulmonary vascular endothelium and released locally or into the circulation. Some of these vasoactive compounds are known to mediate in part the pulmonary blood flow in these critical periods: bradykining, acetylcholine, prostacyclin, leukotrienes, nitric oxide, adenosine (Heymann, 1999; Ziegler et al., 1995).

In adult animals, several studies have demonstrated that AM produces vasodilatation in pulmonary circulation (Cheng et al., 1994; Heaton et al., 1995; Lippton et al., 1994). Very interestingly, AM was demonstrated to significantly increase pulmonary blood flow in late gestation fetal lambs, reaching levels equal to those normally achieved postnatally (de Vroomen et al., 1997). Besides, this AM-induced increase in pulmonary blood flow has mechanistically been characterized to depend largely on NO release and partly on $\mathrm{K}_{\mathrm{ATP}}$ channel activation (Takahashi et al., 2000). These data are currently raising interest in AM as a candidate for the maintenance of fetal vascular pulmonary tone, as well as playing a role in the process of perinatal adaptation to air breathing (Rudolph, 1998). Some other evidence has also been interpreted to be consistent with this hypothesis: (1) AM levels in umbilical blood are similar to those found in adult plasma and may affect the fetus and neonate pulmonary vascular tone (Di Iorio et al., 1999; Hoeldtke et al., 1998); (2) in neonatal piglets, pulmonary AM clearance appears to be increased, thus suggesting a physiological role in mediating pulmonary vasodilation at birth (Sabates et al., 1996).

\section{AM in Gestational Pathologies}

As reviewed above, AM levels in fetoplacental tissues, uterus, maternal and umbilical plasma, and am- niotic fluid are highly increased during normal gestation. These high AM levels together with some physiological data seem to be indicative of AM implication in maternal vascular adaptation to pregnancy, as well as of AM contribution to the regulation of placental and fetus vascular tone. In addition, AM and at least one of its receptors are expressed in a very defined spatiotemporal manner in a great variety of embryonic tissues, also suggesting its role as a growth and differentiation regulator (Montuenga et al., 1997). Taking all this into consideration, it is reasonable to speculate that alterations in the expression of AM or its receptors may be implicated in the pathogenesis of various pregnancy related syndromes. In fact, this hypothesis has been the subject of several investigations, evaluating the expression of $\mathrm{AM}$ and/or $\mathrm{AM}$ receptors in placenta, fetal membranes, and biologic fluids from patients with pregnancy loss or complications as compared to tissues from normal term pregnancies. So far, gestational pathologies such as preeclampsia, intrauterine growth restriction, gestational diabetes mellitus, and hydrops fetalis have been studied. However, the question whether altered expression of AM is a primary event or a secondary compensatory result of abnormal expression of other factors in many of these pregnancy disorders is far from being well understood, and will require further studies.

AM in Preeclampsia. Preeclampsia is a major cause of maternal and neonatal morbidity and mortality, but despite its public health impact, the etiology of this disorder is not well established. It has been suggested that failure of trophoblast invasion of the maternal placental bed may be responsible for impaired placental perfusion (Dekker and Sibai, 1998; Patrick and Roberts, 1999). Another key feature of preeclampsia is that endothelial cells are observed to be disrupted histologically (Khong et al., 1992) and functionally (Roberts, 1999); since endothelium has an essential role in the maintenance of a low vascular resistance in normal pregnancy through the release of several vasoactive agents, an abnormal endothelial function in preeclampsia could contribute to an increase in vascular resistance (Roberts et al., 1989).

Some controversy, however, has arisen from discordances in data of different groups studying AM implication as a pathophysiogical substance in preeclampsia (Di Iorio et al., 1998a): (1) some groups have not found a significant difference in maternal plasma AM concentration between preeclamptic and normotensive pregnant women (Di Iorio et al., 1998c; Jerat et al., 2001; Makino et al., 1999c; Minegishi et al., 1999), whereas others have reported a significant maternal plasma decrease in patients with preeclampsia as compared to normal pregnancies (Hata et al., 1997); (2) concerning AM immunoreactivity in fetoplacental structures from pregnancies with preclampsia, AM staining has either been found to be significantly decreased (specifically in villous syncytiotrophoblasts) with respect to normotensive pregnancies (Kanenishi et al., 2000), or to be increased in the fetal membranes and umbilical artery (Makino et al., 1999c) as compared to controls. Other studies did not find variations in AM immunoreactivity or between both groups (Di Iorio et al., 1998c); (3) finally, with regard to umbilical vein blood and amniotic fluid, AM levels were reported to be significantly 
increased in preeclamptic pregnant women (Di Iorio et al., 1997b), which suggests that increased AM concentrations might be necessary to maintain placental vascular resistance at a physiological level.

Some of the discrepancies in these results could be explained by methodological differences between groups, such as different commercial radioimmunoassay kits or the use of different polyclonal antibodies in immunohistochemical staining (Hinson et al., 2000). Other differences may arise from heterogeneity at sampling or by different criteria in the definition of preeclamptic disorder (Di Iorio et al., 1998a). Possible interaction of AM with other vasoactive agents as a fetal response to compromised intrauterine environment should also be considered. Besides, the presence and distribution of the different AM receptors and RAMPs have yet to be established in normal fetoplacental tissues, and molecular alterations or changes in the expression of these receptors could also be implicated in the patophysiology of preclampsia. Some recent data, however, seem to discard this last proposal, since the increased vascular resistance of preeclamptic placentas was not due to either reduced AM secretion nor to an attenuated vascular responsiveness, thus indicating that AM vasorelaxant pathway is intact in preeclamptic placentas (Jerat et al., 2001).

AM in Intrauterine Growth Restriction. AM levels were found to be significantly increased in umbilical plasma of patients with intrauterine growth restriction (IUGR) as compared to control subjects (Di Iorio et al., 2000). This syndrome is associated with an impairment in uteroplacental blood flow (that may be reduced up to $50 \%$ ) and increased placental resistance, which leads to a persistent suppression of the fetus growth potential in response to reduction in substrate supply (Bates et al., 1996). The increased concentrations of AM in the circulation of IUGR fetuses are interpreted as a compensatory mechanism to the reduced uteroplacental flow caused by the altered production of other vasoactive agents, so that placental vascular resistance and/or fetal circulation would be maintained at physiologic levels (Di Iorio et al., 2000). For instance, levels of vasoactive molecules such as prostacyclin, nitric oxide, or atrial natriuretic peptide have also been reported to be altered in this type of pathology (Di Iorio et al., 1997a; Kingdom et al., 1992; Stuart et al., 1981), and AM could act as a paracrine regulator through the inhibition or stimulation of these factors. A correlation between umbilical AM concentrations in IUGR fetuses and the fetal cerebral/peripheral vessel ratio was also found; this fact suggested a potential role of AM in preferentially dilating cerebral vessels, in order to suppress the reduction of regional cerebral blood flow and prevent ischemic brain injury in IUGR (Di Iorio et al., 2000).

AM in Preterm Labor. The increased expression of AM mRNA and AM-binding sites in the pregnant rat uterus relative to nonpregnant rats suggested that this organ could be a source for the elevated AM maternal plasma levels in pregnancy, and, additionally, that AM in the uterus could also play a role in the control of uterine vascular or nonvascular smooth muscle (Upton et al., 1997). Alternatively, AM could also indirectly affect myometrial contractility during pregnancy by its action on other modulators (such as corticotropin-re- leasing hormone, adrenocorticotropin, prostaglandins, nitric oxide, endothelin), contributing to the control of human parturition (Di Iorio et al., 1998b). In fact, preliminary studies on rat uteri showed a vasorelaxant role for AM by inhibition of the galanin-induced contraction of uterine smooth muscle preparations (Upton et al., 1997). However, Marinoni et al. (1999) reported that AM concentrations in amniotic fluid were significantly elevated in cases of preterm delivery (premature rupture of membranes and preterm labor unresponsive to tocolysis), suggesting that elevated AM levels could be associated with uterine contractility. As suggested, this hypothesis requires further investigation, since the increased concentrations of AM in the amniotic fluid could derive from enhanced synthesis of AM by placenta and fetal membranes stimulated by bacterial products frequently associated with preterm labor, or alternatively, might reflect a compensatory effect of $\mathrm{AM}$ for the increased synthesis and release of other uterotonin substances in this situation (Di Iorio et al., 1998b; Marinoni et al., 1999).

AM in Gestational Diabetes Mellitus. The pathogenesis of gestational diabetes mellitus (GDM) appears to involve poor $\beta$-cell compensation for the insulin resistance that develops in pregnancy, and the majority of pregnant women suffering from GDM have a quantitative defect in insulin secretion (Buchanan et al., 1990). Since AM was characterized as an inhibitor of insulin secretion in the islets both in vivo and in the whole animal (Martínez et al., 1996), the possible contribution of $\mathrm{AM}$ as a factor leading to hyperglicemia in GDM was investigated. When AM plasma levels between pregnant women with or without GDM were compared, no significant difference was found, although a small subset of women with GDM had higher AM levels than any normal pregnant women (Martínez et al., 1999). These data seemed to indicate that AM is not a common contributor to the $\beta$-cell dysfunction in GDM, although it may contribute to it in a subset of women with very high AM levels. Further studies with long-term follow-up for the development of diabetes after pregnancy are needed to further clarify the possible contribution of AM to this $\beta$-cell dysfunction (Martínez et al., 1999).

AM and Hydrops Fetalis. The abundant expression of AM in the placenta and in the early developing heart and blood vessels as well as other fetal organs predicted that a functional study via AM gene ablation in mice could have problems of early in utero lethality. This is in fact what has happened. The two groups that have attempted the development of an AM knock-out mouse have found that $100 \%$ of AM -/- mice die before birth. In particular, Caron and Smithies (2001) performed a study published in a peer-reviewed journal and described that these knock-out mice die at midgestation (between E13.5 and E14.5), presenting a very severe and generalized hydrops fetalis and several cardiovascular abnormalities including overdeveloped ventricular trabeculae and underdeveloped vascular smooth muscle in the large arteries. Caron and Smithies (pages 55-59, this issue) summarize the lessons that have been learnt from AM knock-out and transgenic mice about the functions of AM during embryonic development. 
TABLE 2. AM Expression and Proposed Functions During Embryonic Development

AM expression

$\mathrm{AM}$ in fetoplacental structures and endometrial decidual cells

$\mathrm{AM}$ at different tissues and organs during embryogenesis and organogenesis

AM in maternal plasma

$\mathrm{AM}$ in amniotic fluid

AM in umbilical cord blood

$\mathrm{AM}$ in milk

$\mathrm{AM}$ in uterus and maternal plasma

\section{Proposed function}

Vasculogenesis in primary and secondary villi

Regulation of fetoplacental blood flow

Control of trophoblast invasiveness

Regulation of endocrine secretion by syncitiotrophoblast

Control of cellular growth, differentiation, and migration processess

Maternal vascular and hemodynamic adapatations to pregnancy Maturation processes

Immunologic protection

Control of fetal vascular tone

Control of pulmonary vascular tone in the fetus and in perinatal adaptation to air-breathing

Maturation of gastrointestinal functions

Antimicrobial activity

Control myometrial contractility
The severity of the massive generalized edema in AM -/- embryos led Caron and Smithies (2001) to propose a genetically determined deficiency of AM as one of the possible causes of nonimmune hydrops fetalis (NIHF) in humans. NIHF is the result of an increase in interstitial fluid volume, characterized by ascites and pleural effusions. Nowadays, this syndrome remains a significant cause of human fetal and neonatal mortalility (White, 1999), and chromosome abnormalities, infections, cardiovascular defects, or extreme lysosomal disorders have been found among the most likely causes of this disorder (Lallemand et al., 1999; White, 1999). Despite the many factors known to contribute to the development of hydrops, the pathogenesis of this condition, however, ultimately involves dysfunctional regulation of the fluid balance between vascular and intersitital compartments, e.g., changes in capillary and tissue hydrostatic and oncotic pressures, changes in capillary permeability, or as also suggested for the AM knockout embryo, impaired lymphatic drainage probably due to abnormalities in lymphatic vessel development (Caron and Smithies, 2001). Some studies have also implicated renal function impairment with the pathogenesis of hydrops fetalis, and, in fact, fetuses in which the ureters were bilaterally ligated developed this syndrome (Gibson and Lumbers, 1996). In relation to renal function, AM has been associated with diuretic and natriuretic activities (Ebara et al., 1994; Vari et al., 1996), and thus absence of this peptide could also be proposed to lead to inappropriate fetal renal function and finally contribute to the development of hydrops.

In summary, AM has been found to be very widely expressed during gestation, and similarly to the pluripotent characterization of this peptide in adult life, a broad panel of functions have been proposed also for AM during fetal development. In this sense, AM has been found to be expressed in various fetoplacental structures and maternal decidual cells from early in embryonic development to pregnancy at term, which is suggestive of a putative role of this peptide both at peri-implantation stages and in the regulation of fetoplacental hemodynamics both directly or indirectly through interaction with other vasoactive factors. Besides, high AM levels in maternal and umbilical plasma correlate with the implication of AM in vascular adaptation to pregnancy, and probably also with the regulation of the fetal vascular tone; the physiological significance of AM in amniotic fluid and milk seems to be more related to maturation processes and with immunologic protection of the fetus or the newborn. Additionally, AM has been found to be expressed in a wide variety of tissues and organs during embryonic development in a very defined spatio-temporal manner, which also suggests a role for this peptide in growth and differentiation processes (for proposed AM functions during pregnancy, see Table 2). However, future studies need to be undertaken towards the confirmation of many of those proposed functions, especially with regard to the presence and distribution of different AM receptors, and correlation of physiological and expression studies for this peptide when possible. Finally, but not least important, the identification of factor $\mathrm{H}$ as an AM binding protein with the ability to modify AM function, and the presence of factor $\mathrm{H}$ in several fetal structures, open a new investigative avenue in relation to the role of AM both in normal and pathophysiological states during pregnancy.

\section{ACKNOWLEDGMENTS}

We are thankful to Ms. Ainhoa Urbiola for her technical assistance.

\section{REFERENCES}

Abe K, Minegishi T, Ibuki Y, Kojima M, Kangawa K. 2000. Expression of adrenomedullin in the human corpus luteum. Fertil Steril 74: $141-145$.

Allaker RP, Zihni C, Kapas S. 1999. An investigation into the antimicrobial effects of adrenomedullin on members of the skin, oral, respiratory tract and gut microflora. FEMS Immunol Med Microbiol 23:289-293.

Bass KE, Morrish D, Roth I, Bhardwaj D, Taylor R, Zhou Y, Fisher SJ. 1994. Human cytotrophoblast invasion is up-regulated by epidermal growth factor: evidence that paracrine factors modify this process. Dev Biol 164:550-561.

Bates JA, Evans JA, Mason G. 1996. Differentiation of growth retarded from normally grown fetuses and prediction of intrauterine growth retardation using Doppler ultrasound. Br J Obstet Gynaecol 103:670-675.

Brennecke SP, Castle BM, Demers LM, Turnbull AC. 1985. Maternal plasma prostaglandin E2 metabolite levels during human pregnancy and parturition. Br J Obstet Gynaecol 92:345-349.

Brooimans RA, Hiemstra PS, van der Ark AA, Sim RB, van Es LA, Daha MR. 1989. Biosynthesis of complement factor $\mathrm{H}$ by human umbilical vein endothelial cells. Regulation by $\mathrm{T}$ cell growth factor and IFN-gamma. J Immunol 142:2024-2030.

Buchanan TA, Metzger BE, Freinkel N, Bergman RN. 1990. Insulin sensitivity and B-cell responsiveness to glucose during late pregnancy in lean and moderately obese women with normal glucose 
tolerance or mild gestational diabetes. Am J Obstet Gynecol 162: 1008-1014.

Cameron VA, Fleming AM. 1998. Novel sites of adrenomedullin gene expression in mouse and rat tissues. Endocrinology 139:2253-2264.

Carbillon L, Uzan M, Uzan S. 2000. Pregnancy, vascular tone, and maternal hemodynamics: a crucial adaptation. Obstet Gynecol Surv 55:574-581.

Caron KM, Smithies O. 2001. Extreme hydrops fetalis and cardiovascular abnormalities in mice lacking a functional Adrenomedullin gene. Proc Natl Acad Sci U S A 98:615-619.

Chang CP, Pearse RV, O'Connell S, Rosenfeld MG. 1993. Identification of a seven transmembrane helix receptor for corticotropin-releasing factor and sauvagine in mammalian brain. Neuron 11:1187-1195.

Cheng DY, DeWitt BJ, Wegmann MJ, Coy DH, Bitar K, Murphy WA, Kadowitz PJ. 1994. Synthetic human adrenomedullin and ADM15-52 have potent short-lasting vasodilator activity in the pulmonary vascular bed of the cat. Life Sci 55:L251-256.

Coppock HA, Owji AA, Austin C, Upton PD, Jackson ML, Gardiner JV, Ghatei MA, Bloom SR, Smith DM. 1999. Rat-2 fibroblasts express specific adrenomedullin receptors, but not calcitonin-generelated-peptide receptors, which mediate increased intracellular cAMP and inhibit mitogen-activated protein kinase activity. Biochem J 338:15-22.

Cormier-Regard S, Nguyen SV, Claycomb WC. 1998. Adrenomedullin gene expression is developmentally regulated and induced by hypoxia in rat ventricular cardiac myocytes. J Biol Chem 273:1778717792.

Cornish J, Callon KE, Coy DH, Jiang NY, Xiao L, Cooper GJ, Reid IR. 1997. Adrenomedullin is a potent stimulator of osteoblastic activity in vitro and in vivo. Am J Physiol 273:E1113-1120.

Cross JC, Werb Z, Fisher SJ. 1994. Implantation and the placenta: key pieces of the development puzzle. Science 266:1508-1518.

Cuttitta F, Montuenga LM, Garayoa M, Pío R, Miller MJ, Walsh T, Elsasser T, Martínez A. 1999. The role of adrenomedullin as a growth regulatory peptide in the normal and malignant setting. $J$ Anim Sci 77(Suppl 3):55-69.

de Vroomen M, Takahashi Y, Gournay V, Roman C, Rudolph AM, Heymann MA. 1997. Adrenomedullin increases pulmonary blood flow in fetal sheep. Pediatr Res 41:493-497.

Dekker GA, Sibai BM. 1998. Etiology and pathogenesis of preeclampsia: current concepts. Am J Obstet Gynecol 179:13591375.

Di Iorio R, Marinoni E, Coacci F, La Torre R, Cosmi EV. 1997a. Amniotic fluid nitric oxide and uteroplacental blood flow in pregnancy complicated by intrauterine growth retardation. Br J Obstet Gynaecol 104:1134-1139.

Di Iorio R, Marinoni E, Scavo D, Letizia C, Cosmi EV. 1997b. Adrenomedullin in pregnancy. Lancet 349:328.

Di Iorio R, Marinoni E, Cosmi EV. 1998a. Adrenomedullin in preeclampsia. Lancet 351:676-677.

Di Iorio R, Marinoni E, Cosmi EV. 1998b. New peptides, hormones and parturition. Gynecol Endocrinol 12:429-434.

Di Iorio R, Marinoni E, Letizia C, Alo P, Villaccio B, Cosmi EV. 1998c. Adrenomedullin, a new vasoactive peptide, is increased in preeclampsia. Hypertension 32:758-763.

Di Iorio R, Marinoni E, Letizia C, Villaccio B, Alberini A, Cosmi EV. 1999. Adrenomedullin production is increased in normal human pregnancy. Eur J Endocrinol 140:201-206.

Di Iorio R, Marinoni E, Letizia C, Gazzolo D, Lucchini C, Cosmi EV. 2000. Adrenomedullin is increased in the fetoplacental circulation in intrauterine growth restriction with abnormal umbilical artery waveforms. Am J Obstet Gynecol 182:650-654.

Ding YQ, Zhu LJ, Bagchi MK, Bagchi IC. 1994. Progesterone stimulates calcitonin gene expression in the uterus during implantation. Endocrinology 135:2265-2274.

Ebara T, Miura K, Okumura M, Matsuura T, Kim S, Yukimura T, Iwao H. 1994. Effect of adrenomedullin on renal hemodynamics and functions in dogs. Eur J Pharmacol 263:69-73.

Fisher SJ, Damsky CH. 1993. Human cytotrophoblast invasion. Semin Cell Biol 4:183-188.

Fisher SJ, Cui TY, Zhang L, Hartman L, Grahl K, Zhang GY, Tarpey J, Damsky CH. 1989. Adhesive and degradative properties of human placental cytotrophoblast cells in vitro. J Cell Biol 109:891902.

Fraser SE, Harland RM. 2000. The molecular metamorphosis of experimental embryology. Cell 100:41-55.

García-Lloret MI, Morrish DW, Wegmann TG, Honore L, Turner AR, Guilbert LJ. 1994. Demonstration of functional cytokine-placental interactions: CSF-1 and GM-CSF stimulate human cytotrophoblast differentiation and peptide hormone secretion. Exp Cell Res 214: $46-54$.

Genbacev O, McMaster MT, Fisher SJ. 2000. A repertoire of cell cycle regulators whose expression is coordinated with human cytotrophoblast differentiation. Am J Pathol 157:1337-1351.

Gibson KJ, Lumbers ER. 1996. Fetal hydrops resulting from ureteric ligation in fetal sheep. Proc Aust Physiol Pharmacol Soc 27:195P.

Goodman RP, Killam AP, Brash AR, Branch RA. 1982. Prostacyclin production during pregnancy: comparison of production during normal pregnancy and pregnancy complicated by hypertension. Am J Obstet Gynecol 142:817-822.

Graham CH, Lala PK. 1991. Mechanism of control of trophoblast invasion in situ. J Cell Physiol 148:228-234.

Grosvenor CE, Picciano MF, Baumrucker CR. 1993. Hormones and growth factors in milk. Endocr Rev 14:710-728.

Hammerman MR. 1995. Growth factors in renal development. Semin Nephrol 15:291-299.

Hänze J, Dittrich K, Dotsch J, Rascher W. 1997. Molecular cloning of a novel human receptor gene with homology to the rat adrenomedullin receptor and high expression in heart and immune system. Biochem Biophys Res Commun 240:183-188.

Harvey MB, Leco KJ, Arcellana-Panlilio MY, Zhang X, Edwards DR, Schultz GA. 1995. Proteinase expression in early mouse embryos is regulated by leukaemia inhibitory factor and epidermal growth factor. Development 121:1005-1014.

Hata T, Miyazaki K, Matsui K. 1997. Decreased circulating adrenomedullin in pre-eclampsia. Lancet 350:1600.

Heaton J, Lin B, Chang JK, Steinberg S, Hyman A, Lippton H. 1995. Pulmonary vasodilation to adrenomedullin: a novel peptide in humans. Am J Physiol 268:H2211-2215.

Heymann MA. 1999. Control of the pulmonary circulation in the fetus and during the transitional period to air breathing. Eur J Obstet Gynecol Reprod Biol 84:127-132.

Heymann MA, Soifer SJ. 1989. Control of fetal and neonatal pulmonary circulation. In: Weir EK, Reeves JT, editors. Pulmonary vascular physiology and pathophysiology. New York: Marcel Dekker. pp 33-50.

Hinson JP, Kapas S, Smith DM. 2000. Adrenomedullin, a multifunctional regulatory peptide. Endocr Rev 21:138-167.

Hirata Y, Hayakawa H, Suzuki Y, Suzuki E, Ikenouchi H, Kohmoto O, Kimura K, Kitamura K, Eto T, Kangawa K, Matsuo H, Omata M. 1995. Mechanisms of adrenomedullin-induced vasodilation in the rat kidney. Hypertension 25:790-795.

Hoeldtke NJ, Wagner RK, Moore KH, Calhoun BC, Hume RF. 1998. Adrenomedullin concentrations in umbilical cord plasma of uncomplicated term pregnancies. Am J Obstet Gynecol 179:10711074.

Hoeldtke NJ, Wagner RK, Calhoun BC, Hume RF. 2000. Vasodilatory response of fetoplacental vasculature to adrenomedullin after constriction with the thromboxane sympathomimetic U46619. Am J Obstet Gynecol 183:1573-1578.

Husmann K, Sexton PM, Fischer JA, Born W. 2000. Mouse receptoractivity-modifying proteins $1,-2$ and -3 : amino acid sequence, expression and function. Mol Cell Endocrinol 162:35-43.

Ishimitsu T, Nishikimi T, Saito Y, Kitamura K, Eto T, Kangawa K, Matsuo H, Omae T, Matsuoka H. 1994. Plasma levels of adrenomedullin, a newly identified hypotensive peptide, in patients with hypertension and renal failure. J Clin Invest 94:2158-2161.

Ishizaka Y, Ishizaka Y, Tanaka M, Kitamura K, Kangawa K, Minamino N, Matsuo H, Eto T. 1994. Adrenomedullin stimulates cyclic AMP formation in rat vascular smooth muscle cells. Biochem Biophys Res Commun 200:642-646.

Isumi Y, Minamino N, Katafuchi T, Yoshioka M, Tsuji T, Kangawa K, Matsuo H. 1998. Adrenomedullin production in fibroblasts: its possible function as a growth regulator of Swiss 3T3 cells. Endocrinology 139:2552-2563.

Isumi Y, Kubo A, Katafuchi T, Kangawa K, Minamino N. 1999. Adrenomedullin suppresses interleukin-1beta-induced tumor necrosis factor-alpha production in Swiss 3T3 cells. FEBS Lett 463:110-114.

Jaffe R. 1998. First trimester utero-placental circulation: maternalfetal interaction. J Perinat Med 26:168-174.

Jähnke GD, Miller MJ, Martínez A, Montuenga L, Cuttitta F. 1997. Adrenomedullin expression in the mouse mammary gland: evidence for the mature form in milk. J Mol Endocrinol 19:279-289.

Jerat S, Kaufman S. 1998. Effect of pregnancy and steroid hormones on plasma adrenomedullin levels in the rat. Can J Physiol Pharmacol 76:463-466.

Jerat S, Morrish DW, Davidge ST, Kaufman S. 2001. Effect of adrenomedullin on placental arteries in normal and preeclamptic pregnancies. Hypertension 37:227-231. 
Kanenishi K, Kuwabara H, Ueno M, Sakamoto H, Hata T. 2000. Immunohistochemical adrenomedullin expression is decreased in the placenta from pregnancies with pre-eclampsia. Pathol Int 50:536-540.

Kanenishi K, Kuwabara H, Ueno M, Sato C, Sakamoto H, Hata T. 2001. Change of adrenomedullin concentrations in plasma and amniotic fluid, and human placental adrenomedullin expression with advancing gestation. Placenta 22:244-250.

Kapas S, Clark AJ. 1995. Identification of an orphan receptor gene as a type 1 calcitonin gene-related peptide receptor. Biochem Biophys Res Commun 217:832-838.

Kapas S, Catt KJ, Clark AJ. 1995. Cloning and expression of cDNA encoding a rat adrenomedullin receptor. J Biol Chem 270:2534425347 .

Kato J, Kitamura K, Kangawa K, Eto T. 1995. Receptors for adrenomedullin in human vascular endothelial cells. Eur J Pharmacol 289:383-385.

Katoh F, Kitamura K, Niina H, Yamamoto R, Washimine H, Kangawa $\mathrm{K}$, Yamamoto Y, Kobayashi H, Eto T, Wada A. 1995. Proadrenomedullin N-terminal 20 peptide (PAMP), an endogenous anticholinergic peptide: its exocytotic secretion and inhibition of catecholamine secretion in adrenal medulla. J Neurochem 64: $459-461$.

Katz Y, Gur S, Aladjem M, Strunk RC. 1995. Synthesis of complement proteins in amnion. J Clin Endocrinol Metab 80:2027-2032.

Kawada N, Inoue M. 1994. Effect of adrenomedullin on hepatic pericytes (stellate cells) of the rat. FEBS Lett 356:109-113.

Kennedy SP, Sun D, Oleynek JJ, Hoth CF, Kong J, Hill RJ. 1998. Expression of the rat adrenomedullin receptor or a putative human adrenomedullin receptor does not correlate with adrenomedullin binding or functional response. Biochem Biophys Res Commun 244:832-837.

Khong TY, Sawyer IH, Heryet AR. 1992. An immunohistologic study of endothelialization of uteroplacental vessels in human pregnancy: evidence that endothelium is focally disrupted by trophoblast in preeclampsia. Am J Obstet Gynecol 167:751-756.

Kim S. 1999. Vasoactive substance and vascular remodeling. Nippon Rinsho 57:1508-1513.

Kingdom JC, McQueen J, Connell JM, Whittle MJ. 1992. Maternal and fetal atrial natriuretic peptide levels at delivery from normal and growth retarded pregnancies. Br J Obstet Gynaecol 99:845849 .

Kitamura K, Eto T. 1997. Adrenomedullin: physiological regulator of the cardiovascular system or biochemical curiosity? Curr Opin Nephrol Hypertens 6:80-87.

Kitamura K, Kangawa K, Matsuo H, Eto T. 1998. Structure and function of adrenomedullin and PAMP. In: Martínez A, Cuttitta F, editors. Adrenomedullin. Amsterdam: IOS Press/Ohmsha. pp 2739 .

Kobayashi K, Kubota T, Aso T, Hirata Y, Imai T, Marumo F. 2000. Immunoreactive adrenomedullin (AM) concentration in maternal plasma during human pregnancy and AM expression in placenta. Eur J Endocrinol 142:683-687.

Kohno M, Yokokawa K, Kano H, Yasunari K, Minami M, Hanehira T, Yoshikawa J. 1997. Adrenomedullin is a potent inhibitor of angiotensin II-induced migration of human coronary artery smooth muscle cells. Hypertension 29:1309-1313.

Kohno M, Yasunari K, Minami M, Kano H, Maeda K, Mandal AK, Inoki K, Haneda M, Yoshikawa J. 1999. Regulation of rat mesangial cell migration by platelet-derived growth factor, angiotensin II, and adrenomedullin. J Am Soc Nephrol 10:2495-2502.

Koldovsky O. 1992. Do hormones in milk affect the function of the neonatal intestine? Amer Zool 138:446-454.

Lallemand AV, Doco-Fenzy M, Gaillard DA. 1999. Investigation of nonimmune hydrops fetalis: multidisciplinary studies are necessary for diagnosis: review of 94 cases. Pediatr Dev Pathol 2:432439 .

Letizia C, Subioli S, Rossi G, D’Erasmo E. 1999. Adrenomedullin. A new peptide involved in the regulation of the cardiovascular system. Recenti Prog Med 90:407-411.

Librach CL, Werb Z, Fitzgerald ML, Chiu K, Corwin NM, Esteves RA, Grobelny D, Galardy R, Damsky CH, Fisher SJ. 1991. 92-kD type IV collagenase mediates invasion of human cytotrophoblasts. J Cell Biol 113:437-449.

Lippton H, Chang JK, Hao Q, Summer W, Hyman AL. 1994. Adrenomedullin dilates the pulmonary vascular bed in vivo. J Appl Physiol 76:2154-2156.

Macara LM, Kingdom JPC, Kaufmann P. 1993. Control of fetoplacental circulation. Am J Obstet Gynecol 5:167-179.

Macri C, Miller M, Gray K, Gallagher M, Martínez A, Cuttitta F. 1996a. Adrenomedullin, a new hypotensive peptide, is expressed in maternal decidual cells and fetal cells in first trimester of pregnancy. 176:S155.

Macri CJ, Martínez A, Moody TW, Gray KD, Miller MJ, Gallagher M, Cuttitta F. 1996b. Detection of adrenomedullin, a hypotensive peptide, in amniotic fluid and fetal membranes. Am J Obstet Gynecol 175:906-911.

Macri M, Loup D, McHale M, Jacobs R, Bales L, Sundborg M, Armstrong A, Gehlbach D, Mitchell A, Nelson M, Macri C, Miller MJ, Martínez A, Cuttitta F, Gray K. 1998. Adrenomedullin is widely expressed throughout normal and abnormal reproductive tissues of women: Evidence for cyclic regulation. In: Martínez A, Cuttitta F, editors. Adrenomedullin. Amsterdam: IOS Press/Ohmsha Ltd. pp 207-226.

Makino I, Shibata K, Makino Y, Kangawa K, Kawarabayashi T. 1999a. Adrenomedullin attenuates the hypertension in hypertensive pregnant rats induced by $\mathrm{N}(\mathrm{G})$-nitro-L-arginine methyl ester. Eur J Pharmacol 371:159-167.

Makino I, Shibata K, Makino Y, Kangawa K, Kawarabayashi T. 1999b. Potentiation of the hypotensive effect of adrenomedullin in pregnant rats. Eur J Pharmacol 385:129-136.

Makino Y, Shibata K, Makino I, Ono Y, Kangawa K, Kawarabayashi T. 1999c. Expression of adrenomedullin in feto-placental circulation of human normotensive pregnant women and pregnancy-induced hypertensive women. Endocrinology 140:5439-5442.

Marinoni E, Di Iorio R, Letizia C, Villaccio B, Scucchi L, Cosmi EV. 1998. Immunoreactive adrenomedullin in human fetoplacental tissues. Am J Obstet Gynecol 179:784-787.

Marinoni E, Di Iorio R, Letizia C, Villaccio B, Alberini A, Cosmi EV. 1999. Amniotic fluid concentrations of adrenomedullin in preterm labor. Obstet Gynecol 93:964-967.

Martínez A, Weaver C, López J, Bhathena SJ, Elsasser TH, Miller MJ, Moody TW, Unsworth EJ, Cuttitta F. 1996. Regulation of insulin secretion and blood glucose metabolism by adrenomedullin. Endocrinology 137:2626-2632.

Martínez A, Elsasser TH, Muro-Cacho C, Moody TW, Miller MJ, Macri CJ, Cuttitta F. 1997. Expression of adrenomedullin and its receptor in normal and malignant human skin: a potential pluripotent role in the integument. Endocrinology 138:5597-5604.

Martínez A, Cuttitta F, Teitelman G. 1998. Expression pattern for adrenomedullin during pancreatic development in the rat reveals a common precursor with other endocrine cell types. Cell Tissue Res 293:95-100.

Martínez A, Elsasser TH, Bhathena SJ, Pío R, Buchanan TA, Macri CJ, Cuttitta F. 1999. Is adrenomedullin a causal agent in some cases of type 2 diabetes? Peptides 20:1471-1478.

Mastrogiannis DS, O'Brien WF, Krammer J, Benoit R. 1991. Potential role of endothelin-1 in normal and hypertensive pregnancies. Am J Obstet Gynecol 165:1711-1716.

McLatchie LM, Fraser NJ, Main MJ, Wise A, Brown J, Thompson N, Solari R, Lee MG, Foord SM. 1998. RAMPs regulate the transport and ligand specificity of the calcitonin-receptor-like receptor. Nature 393:333-339

Miller MJ, Martínez A, Unsworth EJ, Thiele CJ, Moody TW, Elsasser T, Cuttitta F. 1996. Adrenomedullin expression in human tumor cell lines. Its potential role as an autocrine growth factor. J Biol Chem 271:23345-23351.

Minegishi T, Nakamura M, Abe K, Tano M, Andoh A, Yoshida M, Takagi T, Nishikimi T, Kojima M, Kangawa K. 1999. Adrenomedullin and atrial natriuretic peptide concentrations in normal pregnancy and pre-eclampsia. Mol Hum Reprod 5:767-770.

Montuenga LM, Martínez A, Miller MJ, Unsworth EJ, Cuttitta F. 1997. Expression of adrenomedullin and its receptor during embryogenesis suggests autocrine or paracrine modes of action. Endocrinology 138:440-451.

Montuenga LM, Mariano JM, Prentice MA, Cuttitta F, Jakowlew SB. 1998. Coordinate expression of transforming growth factor-beta1 and adrenomedullin in rodent embryogenesis. Endocrinology 139: $3946-3957$.

Moody TW, Coy D, Cuttitta F, Montuenga LM. 2000. Proadrenomedullin $\mathrm{NH}(2)$-terminal 20 peptide (PAMP) and adrenomedullin bind to teratocarcinoma cells. Peptides 21:101-107.

Morrish DW, Bhardwaj D, Dabbagh LK, Marusyk H, Siy O. 1987. Epidermal growth factor induces differentiation and secretion of human chorionic gonadotropin and placental lactogen in normal human placenta. J Clin Endocrinol Metab 65:1282-1290.

Morrish DW, Bhardwaj D, Paras MT. 1991. Transforming growth factor beta 1 inhibits placental differentiation and human chorionic gonadotropin and human placental lactogen secretion. Endocrinology 129:22-26.

Morrish DW, Linetsky E, Bhardwaj D, Li H, Dakour J, Marsh RG, Paterson MC, Godbout R. 1996. Identification by subtractive hy- 
bridization of a spectrum of novel and unexpected genes associated with in vitro differentiation of human cytotrophoblast cells. Placenta 17:431-441.

Nikitenko LL, MacKenzie IZ, Rees MC, Bicknell R. 2000. Adrenomedullin is an autocrine regulator of endothelial growth in human endometrium. Mol Hum Reprod 6:811-819.

Nilsen-Hamilton M. 1990. Transforming growth factor-beta and its actions on cellular growth and differentiation. Curr Top Dev Biol 24:95-136.

Nilsen-Hamilton M. 1994. Introduction: fibroblast growth factors and their receptors in development and disease. Mol Reprod Dev 39:4142.

Njuki F, Nicholl CG, Howard A, Mak JC, Barnes PJ, Girgis SI, Legon S. 1993. A new calcitonin-receptor-like sequence in rat pulmonary blood vessels. Clin Sci (Colch) 85:385-388.

Nuki C, Kawasaki H, Kitamura K, Takenaga M, Kangawa K, Eto T, Wada A. 1993. Vasodilator effect of adrenomedullin and calcitonin gene-related peptide receptors in rat mesenteric vascular beds. Biochem Biophys Res Commun 196:245-251.

Patrick T, Roberts JM. 1999. Current concepts in preeclampsia. MCN Am J Matern Child Nurs 24:193-200; quiz 201.

Pío R, Martínez A, Elsasser TH, Cuttitta F. 2000. Presence of immunoreactive adrenomedullin in human and bovine milk. Peptides 21:1859-1863.

Pío R, Martínez A, Unsworth EJ, Kowalak JA, Bengoechea JA, Zipfel PF, Elsasser TH, Cuttitta F. 2001. Complement Factor H is a serum-binding protein for adrenomedullin, and the resulting complex modulates the bioactivities of both partners. J Biol Chem 276:12292-12300.

Pittenger MF, Mackay AM, Beck SC, Jaiswal RK, Douglas R, Mosca JD, Moorman MA, Simonetti DW, Craig S, Marshak DR. 1999. Multilineage potential of adult human mesenchymal stem cells. Science 284:143-147.

Poyner DR. 1997. Molecular pharmacology of receptors for calcitoningene-related peptide, amylin and adrenomedullin. Biochem Soc Trans 25:1032-1036.

Roberts JM. 1999. Objective evidence of endothelial dysfunction in preeclampsia. Am J Kidney Dis 33:992-997.

Roberts JM, Taylor RN, Musci TJ, Rodgers GM, Hubel CA, McLaughlin MK. 1989. Preeclampsia: an endothelial cell disorder. Am J Obstet Gynecol 161:1200-1204.

Rudolph AM. 1998. Adrenomedullin: its role in perinatal adaptation. Acta Paediatr 87:235-236.

Sabates B, Granger T, Choe E, Pigott J, Lippton H, Hyman A, Flint L, Ferrara J. 1996. Adrenomedullin is inactivated in the lungs of neonatal piglets. J Pharm Pharmacol 48:578-580.

Samson WK, Murphy T, Schell DA. 1995. A novel vasoactive peptide, adrenomedullin, inhibits pituitary adrenocorticotropin release. Endocrinology 136:2349-2352.

Serrano J, Uttenthal LO, Martínez A, Fernández AP, Martínez de Velasco J, Alonso D, Bentura ML, Santacana M, Gallardo JR, Martínez-Murillo R, Cuttitta F, Rodrigo J. 2000. Distribution of adrenomedullin-like immunoreactivity in the rat central nervous system by light and electron microscopy. Brain Res 853:245-268.

Sexton PM, Albiston A, Morfis M, Tilakaratne N. 2001. Receptor activity modifying proteins. Cell Signal 13:73-83.

Smith WC. 1999. TGF beta inhibitors. New and unexpected requirements in vertebrate development. Trends Genet 15:3-5.

Stabile I, Nicolaides KH, Bach A, Teisner B, Rodeck C, Westergaard JG, Grudzinskas JG. 1988. Complement factors in fetal and maternal blood and amniotic fluid during the second trimester of normal pregnancy. Br J Obstet Gynaecol 95:281-285.

Stuart MJ, Clark DA, Sunderji SG, Allen JB, Yambo T, Elrad H, Slott JH. 1981. Decrease prostacyclin production: a characteristic of chronic placental insufficiency syndromes. Lancet 1:1126-1128.

Sugo S, Minamino N, Kangawa K, Miyamoto K, Kitamura K, Sakata J, Eto T, Matsuo H. 1994. Endothelial cells actively synthesize and secrete adrenomedullin. Biochem Biophys Res Commun 201:11601166.
Takahashi Y, De Vroomen M, Roman C, Heymann MA. 2000. Mechanisms of calcitonin gene-related peptide-induced increases of pulmonary blood flow in fetal sheep. Am J Physiol Heart Circ Physiol 279:H1654-1660.

Taniguchi Y. 1999. Effect of practice in bilateral and unilateral reaction-time tasks. Percept Mot Skills 88:99-109.

Teitel DF, Iwamoto HS, Rudolph AM. 1990. Changes in the pulmonary circulation during birth-related events. Pediatr Res 27:372378.

Timmerman JJ, van der Woude FJ, van Gijlswijk-Janssen DJ, Verweij CL, van Es LA, Daha MR. 1996. Differential expression of complement components in human fetal and adult kidneys. Kidney Int 49:730-740.

Tsuruda T, Kato J, Kitamura K, Kuwasako K, Imamura T, Koiwaya Y, Tsuji T, Kangawa K, Eto T. 1998. Adrenomedullin: a possible autocrine or paracrine inhibitor of hypertrophy of cardiomyocytes. Hypertension 31:505-510.

Tsuruda T, Kato J, Kitamura K, Kawamoto M, Kuwasako K, Imamura T, Koiwaya Y, Tsuji T, Kangawa K, Eto T. 1999. An autocrine or a paracrine role of adrenomedullin in modulating cardiac fibroblast growth. Cardiovasc Res 43:958-967.

Upton PD, Austin C, Taylor GM, Nandha KA, Clark AJ, Ghatei MA, Bloom SR, Smith DM. 1997. Expression of adrenomedullin (ADM) and its binding sites in the rat uterus: increased number of binding sites and ADM messenger ribonucleic acid in 20-day pregnant rats compared with nonpregnant rats. Endocrinology 138:2508-2514.

Vari RC, Adkins SD, Samson WK. 1996. Renal effects of adrenomedullin in the rat. Proc Soc Exp Biol Med 211:178-183.

Walsh TJ, Martínez A, Perter J, Unsworth E, Cuttitta F. 1998. Antimicrobial activity of adrenomedullin and its gene-related peptides. Clin Infect Dis 23:96.

Washimine H, Asada Y, Kitamura K, Ichiki Y, Hara S, Yamamoto Y, Kangawa K, Sumiyoshi A, Eto T. 1995. Immunohistochemical identification of adrenomedullin in human, rat, and porcine tissue. Histochem Cell Biol 103:251-254.

White LE. 1999. Nonimmune hydrops fetalis. Neonatal Netw 18:2530 .

Wimalawansa SJ. 1997. Amylin, calcitonin gene-related peptide, calcitonin, and adrenomedullin: a peptide superfamily. Crit Rev Neurobiol 11:167-239.

Withers DJ, Coppock HA, Seufferlein T, Smith DM, Bloom SR, Rozengurt E. 1996. Adrenomedullin stimulates DNA synthesis and cell proliferation via elevation of cAMP in Swiss 3T3 cells. FEBS Lett 378:83-87.

Yagel S, Parhar RS, Jeffrey JJ, Lala PK. 1988. Normal nonmetastatic human trophoblast cells share in vitro invasive properties of malignant cells. J Cell Physiol 136:455-462.

Yagel S, Casper RF, Powell W, Parhar RS, Lala PK. 1989. Characterization of pure human first-trimester cytotrophoblast cells in long-term culture: growth pattern, markers, and hormone production. Am J Obstet Gynecol 160:938-945.

Yamaguchi T, Baba K, Doi Y, Yano K. 1995. Effect of adrenomedullin on aldosterone secretion by dispersed rat adrenal zona glomerulosa cells. Life Sci 56:379-387.

Yotsumoto S, Shimada T, Cui CY, Nakashima H, Fujiwara H, Ko MS. 1998. Expression of adrenomedullin, a hypotensive peptide, in the trophoblast giant cells at the embryo implantation site in mouse. Dev Biol 203:264-275.

Zhao Y, Hague S, Manek S, Zhang L, Bicknell R, Rees MC. 1998. PCR display identifies tamoxifen induction of the novel angiogenic factor adrenomedullin by a non estrogenic mechanism in the human endometrium. Oncogene 16:409-415.

Zhu LJ, Bagchi MK, Bagchi IC. 1998. Attenuation of calcitonin gene expression in pregnant rat uterus leads to a block in embryonic implantation. Endocrinology 139:330-339.

Ziegler JW, Ivy DD, Kinsella JP, Abman SH. 1995. The role of nitric oxide, endothelin, and prostaglandins in the transition of the pulmonary circulation. Clin Perinatol 22:387-403. 